\title{
Objective Truth and the Practice Relativity of Justification in the Pragmatic Turn
}

James R. O'Shea

\section{(2) OpenEdition Journals}

Electronic version

URL: https://journals.openedition.org/ejpap/839

DOI: $10.4000 /$ ejpap.839

ISSN: 2036-4091

\section{Publisher}

Associazione Pragma

Electronic reference

James R. O'Shea, "Objective Truth and the Practice Relativity of Justification in the Pragmatic Turn", European Journal of Pragmatism and American Philosophy [Online], III-2 | 2011, Online since 29

December 2011, connection on 21 September 2021. URL: http://journals.openedition.org/ejpap/839 DOI: https://doi.org/10.4000/ejpap.839

This text was automatically generated on 21 September 2021.

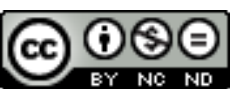

Author retains copyright and grants the European Journal of Pragmatism and American Philosophy right of first publication with the work simultaneously licensed under a Creative Commons Attribution-

NonCommercial-NoDerivatives 4.0 International License. 


\title{
Objective Truth and the Practice Relativity of Justification in the Pragmatic Turn
}

\author{
James R. O'Shea
}

1 In the beginning, as they say, was the 'pragmatic maxim' of Peirce and James. Peirce's early formulation of the maxim in "How to Make Our Ideas Clear" ran as follows:

Consider what effects, which might conceivably have practical bearings, we conceive the object of our conception to have. Then our conception of these effects is the whole of our conception of the object. (Peirce 1878: 132; cf. Bernstein 2010:

2-3; and O'Shea 2008: 208-13)

2 At its core, pragmatism thus originated as a method for clarifying the conceptual meaning or content of any term or idea. A common theme running throughout the subsequent attempted clarifications of this maxim or 'principle of pragmatism,' by both Peirce and James (cf. James 1898: 347-9, and 1907: 377-8), was the idea that, as Peirce puts it, "there is no distinction of meaning so fine as to consist in anything but a possible difference of practice" (1992: 131). Of particular importance for determining the conceptual content of a given belief or assertion, on this pragmatist outlook, is the role that such beliefs and their constituent concepts play (Peirce emphasizes inference and James the "leadings" of ideas in experience and action) within what Sellars would later call the "logical space of reasons" (cf. Bernstein 2010: 49). ${ }^{1}$

3 Since questions concerning the rational justification and cognitive merits of a given assertion will of course depend partly upon an assessment of its meaning; and since meaning, for the pragmatist (let us simplify), is determined by inferential and other roles within a practice; it is not surprising that there is generally a tight connection for pragmatists between issues of rational justification on the one hand, and the particularities of practice on the other. Furthermore, when the pragmatic maxim with its broadly inferentialist implications for meaning and justification is then applied to the concept of truth, it is also not surprising to find Peirce and James and their pragmatist 
descendants tightly linking (in some cases identifying) truth with what is justifiable or 'good in the way of belief' relative to the normative standards of given practices and working conceptual frameworks. However, since pragmatists themselves emphasize that such normative standards and such working frameworks are plural and often conflicting (perhaps in some cases incommensurable), there has been a perennial tension within pragmatism between the relativity to practices of meaning and justification on the one hand, and our deep-seated and seemingly warranted beliefs in the objectivity of truth on the other. In "Sources of Pluralism in William James" (2000) I argued that these two tenets were explored in philosophically groundbreaking but ultimately not entirely satisfactory ways in James's own 'conceptual scheme pluralism.'

Throughout the impressive range and depth of his outstanding new book, The Pragmatic Turn (2010), Richard Bernstein insightfully explores the philosophical consequences of this pragmatist outlook for past and present theories of meaning, truth, and justification, from the classical pragmatists through Hegel and Sellars to Habermas, Rorty, Putnam, Davidson, Brandom, McDowell, and other recent thinkers. ${ }^{2}$ In particular a central theme in this book, as in his earlier Beyond Objectivism and Relativism: Science, Hermeneutics, and Praxis (1983), is Bernstein's contention that the "pragmatists provide a philosophical orientation that is truly beyond the sterile opposition (and oscillation) between objectivism and relativism" (Bernstein 2010: 29; cf. 53-5).

5 However, in one of the most insightful chapters of the book, chapter 5 on "Pragmatism, Objectivity, and Truth," Bernstein shows himself to be well aware that what he here cites as a virtue of pragmatism has also always been, and continues to be, a problem for pragmatists, perhaps the deepest and most persistent problem of all. What follows are some remarks on Bernstein's most recent treatment of this difficult problem: that is, the problem of how those of us who have taken the 'pragmatic turn' can best account for our deep-seated intuitions concerning truth and objectivity in light of the definitive pragmatist emphasis on the practice relativity of meaning and justification. This is a problem that may well be "a progressive narrative" within the pragmatist tradition, as Bernstein argues (2010: 123). However, the difficulties remain pervasive enough to make it hard to see how exactly one should take the claim that the pragmatic turn has provided a philosophical orientation that is truly beyond the opposition and oscillation between intuitions concerning the objectivity and the practice relativity of our judgments. At several points in what follows I will use Sellars' outlook as a helpfully shared (though of course not an entirely agreed) frame of reference. ${ }^{3}$

In chapter 5 and elsewhere in the book, Bernstein helpfully portrays the "interminable oscillation"' between, on the one hand, those philosophers who by temperament (in James's sense) have the "realistic' intuition" that "there is a reality 'out there' that is independent of any of our subjective beliefs," and according to whom our aim is to "achieve objective knowledge" that "corresponds to" (107) and "must somehow correctly represent this objective reality" (109). And on the other hand, there are "those who argue that this way of positing the problem leads to dead-ends and aporias," for despite "the many important differences among Wittgenstein, Quine, Davidson, Sellars, Rorty, McDowell, Brandom (and many others), they all contribute to undermining our confidence in any of the traditional correspondence theories" (109). On this latter view, it seems, if "we are to give a proper account of objectivity, we must give up on any and all forms of representationalism; we must appeal to intersubjective (or better social) justificatory practices" (109). Having swung this way, however, now "the pendulum 
swings back" again. For the "champions of objectivist or realist intuitions" argue that the latter social-justificatory reconceptions of truth and objectivity fail to capture the plausible senses in which our judgments are (as McDowell puts it) answerable to the world, not just answerable to our partners in the social conversation (109-10). This nicely sets up the basic oscillation (of course there are many different issues raised within it), and I think Bernstein has done an important service in stressing both the importance and the centrality of this issue for those philosophers who have taken the pragmatic turn.

However, for anyone like myself who has taken the pragmatic turn, some of Bernstein's particular remarks about the issue of "correspondence to the objective facts" (108), in setting up the oscillation, should be unsettling. For Bernstein asserts, in his own voice it seems, that "in many straightforward cases" we can "just look and see" that, for example, "it is now raining outside"; and that in such cases we can "even say that there is a direct comparison between my statement and the reality to which it refers. 'Correspondence' or 'agreement' works in such straightforward, noncontroversial instances [...]" (108). Here I think Bernstein's robust common sense threatens to lead him astray and to get the better of his more reflective pragmatist insights - particularly in relation to his welcome pragmatist embrace of Sellars' account of the Myth of the Given. For Bernstein immediately goes on to contrast the above "noncontroversial" cases of simple perceptual correspondence with "more complicated cases of philosophical, scientific, mathematical, or historical assertions" (moral assertions would also usually figure prominently in such a list), and he states: “Here we can't simply look and see; rather, we are required to give reasons to support our claims about what is objectively true" (108).

But of course the central lesson of the pragmatist, Kantian, and neo-Hegelian rejection of the Given accepted by Sellars, Rorty, McDowell, Brandom, and by Bernstein himself (cf., in particular, 50-2, including endnote 24), is that even in the case of "straightforward" perceptual knowledge "we are required to give reasons"; or more accurately, for such perceptual responses to constitute the cognition of any object at all, the perceiver must be such as to be able to rationally respond to challenges and give reasons if the question arises - that is, as Bernstein admits concerning the "more complicated" cases, "to support our claims about what is objectively true." "Noncontroversial" instances of direct perceptual knowledge of the world are possible, on this view, only if the very contents of our non-inferential perceptual 'takings' are conceptually structured contents (or in the case of animals and infants, are perhaps proto-conceptual contents). And the possession of conceptual content in general for the pragmatist, as we have seen, depends upon our responses having been shaped by an inferentially structured practice or "form of life": a logical space of reason-giving. On this both Peirce and the Sellarsians - and I would think Bernstein - all agree.

9 Perhaps the reason that Bernstein is inclined to make this sort of slip (as it seems to me) in relation to "noncontroversial" perceptual knowledge has to do with his interesting view that Peirce's conception of Secondness, "which acknowledges the brute compulsiveness of experience" (52), "helps to undercut much of the sterile debate about realism and antirealism in contemporary philosophy" (136). As Bernstein puts this point quite strongly in chapter 6, "Experience after the Linguistic Turn":

I don't think we need anything more than Secondness to do justice to what philosophers call their 'realistic intuitions.' We do not need to reify a realm of facts that exist independently of any language, thought, or inquiry. Peirce does justice to the fallibility and openness of all justificatory practices and inquiry without losing touch with a reality 'that is independent of vagaries of me and you' (Peirce 1992, 
52). Contrary to the prevailing prejudice that the linguistic turn displaces oldfashioned talk about experience, Peirce's conception of experience helps us to escape from some of the dead-ends of the linguistic turn. (136) placed by Bernstein himself in the preceding chapter 5 (i.e., on "Pragmatism, Objectivity, and Truth") on the "progressive narrative" that he shows stretches from Peirce up to Robert Brandom's more recent linguistic conception of the necessary structural form of objectivity, in chapter 8 of Making It Explicit. In Bernstein's chapter 5, Brandom's account emerges from the fray of recent pragmatist accounts as what Bernstein clearly seems to regard (given his criticisms of the other neo-pragmatist candidates in that chapter) as a most promising and "robust pragmatic understanding of justification, truth, intersubjectivity, and objectivity" (122-3). By clear implication Bernstein regards Brandom's account as the general sort of account, at the conceptual level of the 'space of reasons' (cf. Peirce's 'Thirdness'), that Bernstein thinks is needed in order to handle the central 'oscillation' between pragmatic relativity and objective realism.

11

is an important philosophical reason why we thus need more than Secondness "to do justice to what philosophers call their 'realistic intuitions," although I do want to agree with Bernstein on the importance of the role played by Peircean Secondness as "the brute constraining force of experience" (134). Bernstein expresses the important truth in the idea of the "brute compulsiveness" of experience this way: "Acknowledgement of this bruteness - the way experience 'says NO!' - is required to make sense of the selfcorrective character of inquiry and experimentation" (134). But of course as Bernstein is well aware, in rejecting the Myth of the Given both Peirce and Sellars hold that "as soon as we raise the question, 'What constrains us?' we are dealing with Thirdness" (135), i.e., with inferentially articulable conceptual content, which is what in Peirce corresponds to the normative-epistemic dimension of the Sellarsian 'space of reasons.' For the question of what it is in reality that our experience forces us to somehow accommodate in the process of self-correcting empirical inquiry depends entirely in this respect on the concepts that constitute this aspect of our direct perceptual experiences as cognitions of objects. All of the pragmatists, as far as I know, accept this point from Kant. Certainly Sellars and Peirce do, and so, I think, does Bernstein. But of course what the proper and steady recognition of this point immediately does is to land us right back - 'Secondness,' 'Thirdness' and all - to the fundamental problem of making sense of a properly pragmatist account of objectivity in the face of the plurality of 'spaces' of reason and the relativity to practices of meaning and justification.

John McDowell's Mind and World is in effect a sophisticated metaphilosophical attempt although he would not put it this way - to intelligibly free ourselves to recognize that all that is needed for an adequate account of objectivity (or of the 'objective purport' of our concepts) is to recognize that our conceptual activity within the space of reasons (cf. Peirce's Thirdness), when things go right, is a passively elicited (cf. Peirce's Secondness) direct openness to the structure of facts that obtain in the world. This is an important recent outlook on the problem of objectivity, although Bernstein indicates that he does "not think that McDowell thus far has provided more than hints about how" we are "to rethink the concept of nature in a way that shows how it is continuous with the higher reaches of rationality and thought" (102). At any rate, it is certainly clear that an appeal to the brute constraining element or Secondness of experience is not sufficient to address the key 'realist' questions concerning how we are to make intelligible to ourselves the

European Journal of Pragmatism and American Philosophy, III-2 | 2011 
objective truth of any given experience or judgment within any given 'space of reasons,' given the facts of plurality and relativity to practices that Bernstein and I agree are put centre stage by the pragmatists.

13 As Bernstein explains (110-6), Peirce of course also had a different kind of pragmatist answer to the problem of objective reality, which we may call the ideal long run view. Thus Peirce contends that "human opinion universally tends in the long run to a definite form, which is the truth," and that the "real, then, is that which, sooner or later, information and reasoning would finally result in, and which is therefore independent of the vagaries of me and you" (Peirce 1992: 89, 52, quoted in Bernstein 2010: 111). A version of this view was also defended by Sellars (1967, chapter 5, cf. Jay Rosenberg 2007), and more recently and fully by Cheryl Misak in Truth and the End of Inquiry: A Peircean Account of Truth (1991; cf. 2007). ${ }^{4}$

14 In Sellars, put brusquely (cf. O'Shea 2007, chapter 6, for details), this took the form, firstly, of a general account of truth as correct semantic assertibility relative to the rules of any given conceptual framework or 'language game.' This comprehensive aspect of his account is motivated by Sellars' general pragmatist outlook on meaning, truth, and justification along the lines crudely sketched above but developed admirably by Bernstein throughout his book. Interestingly, in this first respect Sellars developed a broadly pluralist conception concerning the different domains of truth, according to which the unified notion of truth as correct semantic assertibility consists in different properties in different regions of human experience and inquiry. For example (again, roughly put), in mathematics truth is provability, Sellars suggests; in morality truth is basically consilience with intersubjectively instituted communal 'oughts,' including the problematic regulative ideal of a community of all rational beings (see O'Shea 2007: chapter 7 for details); and in relation to empirical "matters-of-fact" truth consists in a representational correspondence to the world (more on this presently). It is in relation to the latter conception of empirical truth that Sellars develops, secondly, his Peircean long run view of truth, and here I just want to close with a few observations concerning these views from Sellars in relation to Bernstein's chapter 5 with its criticism of long run views and its showcasing of Brandom's formal-structural conception of objectivity.

15 I do not think that Bernstein's particular objections to the long run regulative idea of objective empirical truth are persuasive (cf. 112-6), at least not in the case of Sellars' view of self-correcting theory-succession in science (Bernstein focuses on Misak; on Sellars on conceptual change and convergence, cf. O'Shea 2007, chapter 6). For example, Sellars (in these respects like Thomas Kuhn) would agree with Bernstein that we cannot "specify now the norms that will govern future inquiry" (112); that it "is an illusion to think that there are ahistorical determinate standards to which we can appeal that will sharply distinguish once and for all what 'really' are good or better reasons" (114); and that the "history of science" shows "that standards of argumentation and justification have changed in ways that no scientist or philosopher might have anticipated" (114). However, it must be admitted that there are other worries about such long run views, including Sellars,' and it seems to me that there is a more general worry concerning truth and objectivity that motivates the development of such convergence views, but which pertains to human cognition and practices in general. This will bring us back, finally, to Bernstein's "progressive narrative" in chapter 5 , which culminates - not to suggest that Bernstein uncritically or wholly accepts this view - in Brandom's conception of objectivity. According to the latter, as Bernstein puts it in his own words, "built into the 
very structure of social discursive practices is a distinction between what is 'merely' subjective and what is objective, what seems to be so and what really is so" (122).

Again, let us take the Sellarsian 'space of reasons' as one way of raising the problem of realism and objectivity in the face of the relativity to practices of meaning and justification, as discussed earlier. The final section of Brandom's shorter book, Articulating Reasons, entitled "Objectivity," nicely lays out the sort of "structural dilemma" here between the question of the correct assertibility of a given claim by those following the rules of a given practice, and the question of "getting things right" objectively "according to a standard set by the things about which one is speaking," and asking: "Is the claim correct in the sense that things really are as it says they are?" (Brandom 2000: 197-8). Brandom's solution involves showing that the complex discursive interplay between our normative commitment and our entitlement to claims enables a systematic distinction in any propositionally contentful discourse between the truth conditions and the assertibility conditions of those claims: for example, "between the contents of ordinary empirical claims and the contents of any claims about who is committed or entitled to what" (ibid.: 201).

But in this light let us finally return to the remarks on Sellars above concerning the systematic differences (as discussed in his Science and Metaphysics, chapter 5) between the ways in which moral truths, mathematical truths, and empirical truths are objective setting aside all issues about the long run of science, and just considering any empirical framework or domain of cognition whatsoever (whether 'manifest' or 'scientific'). Here, I think, lies a most difficult and unresolved source of the dilemma concerning realism and objectivity for those who have taken the pragmatic turn. Can a 'space of reasons' pragmatist, while rejecting implausible positivistic 'fact vs. value' distinctions, nonetheless defend a plausible and principled distinction between (1) the ways in which perceptual-empirical claims (i.e., Sellars' "matter-of-factual," world-representational claims), such as there is a coffee cup on this table, are objectively true by corresponding to the layout of things in the environment (to put it crudely), and (2) the ways in which moral, mathematical, aesthetic, political, and other claims can be objectively true according to the normative rules of a given practice? Brandom's normative-structural conception of objectivity and of the representation of facts across both (1) and (2) affords us no grounds, as far as I can see, for any principled distinction of this kind.

I cannot argue this point further here, but I do not think that the issues pertaining to realism and objectivity will cease to be seen by philosophers at large as more of a problem for than a virtue of the pragmatist tradition until someone succeeds, as Sellars and some others have tried to do (independently of any stronger claims concerning the Peircean long run of science), in the task of embedding within pragmatism a rigorous and defensible distinction between the domain of matter-of-factual perceptual and (broadly) scientific truths about empirical objects in general on the one hand, and on the other hand all the other domains in which our claims to objective truth can be well-grounded but in different ways appropriate to those domains. I think there are grounds to believe that a global pragmatism can and should make this sort of principled realist distinction from the inside, as it were, without losing the insights that make it worth wholeheartedly embracing Bernstein's Pragmatic Turn. 


\section{BIBLIOGRAPHY}

BERNSTEIN R., (1964), “Peirce's Theory of Perception,” in Moore E. C., \& Robin R.(eds.), Studies in the Philosophy of Charles Sanders Peirce: Second Series, Amherst, MA, University of Massachusetts, 165-84.

BERNSTEIN R., (1966), “Sellars' Vision of Man-in-the-universe,” Review of Metaphysics, 20 (1), 113-43; and 20 (2), 290-316.

BERNSTEIN R., (1983), Beyond Objectivism and Relativism: Science, Hermeneutics, and Praxis, Philadelphia, University of Pennsylvania Press.

BERnSteIn R., (2010), The Pragmatic Turn, Cambridge, Polity Press.

BRANDOM R., (1994), Making It Explicit: Reasoning, Representing, and Discursive Commitment, Cambridge, Harvard University Press.

BRANDOM R., (2000), Articulating Reasons: An Introduction to Inferentialism, Cambridge, Harvard University Press.

JAMES W., (1898), “Philosophical Conceptions and Practical Results,” in McDermott J. (ed.), (1977), The Writings of William James: A Comprehensive Edition, Chicago and London, University of Chicago Press.

JAMES W., (1907), Pragmatism: A New Name for Some Old Ways of Thinking and The Meaning of Truth: A Sequel to 'Pragmatism.'

MCDOWELL J., (1994), Mind and World, Harvard, Harvard University Press.

MISAK C., (1991), Truth and the End of Inquiry: A Peircean Account of Truth, Oxford, Oxford University Press, expanded edition in 2004.

MISAK C., (2007), "Pragmatism and Deflationism," in Misak C. (ed.), New Pragmatists, Oxford, Oxford University Press, 68-90.

O'SHEA J., (2000), “Sources of Pluralism in William James," in Baghramian M., \& Ingram A. (eds.), Pluralism: The Philosophy and Politics of Diversity, London, Routledge, 17-43.

o'SHEA J., (2007), Wilfrid Sellars: Naturalism with a Normative Turn, Cambridge, Polity Press.

o'shea J., (2008), “American Philosophy in the Twentieth Century,” in Moran D. (ed.), The Routledge Companion to Twentieth Century Philosophy, London, Routledge, 204-53.

PEIRCE C. S., (1992), The Essential Peirce: Selected Philosophical Writings, vol. 1, Houser N., \& Kloesel C. (eds.), Bloomington, Indiana University Press.

ROSENBERG J. F., (2007), Wilfrid Sellars: Fusing the Images, Oxford, Oxford University Press.

SEllars W., (1963), Science, Perception, and Reality, Atascadero, Ridgeview Publishing Company (reissued 1991).

SELLARS W., (1967), Science and Metaphysics: Variations on Kantian Themes, Atascadero, Ridgeview Publishing Company (reissued 1992). 


\section{NOTES}

1. Throughout this paper I adopt the practice common among philosophers of using 'single quotation marks' for mentioning items and for 'scare-quotes,' while reserving 'double quotation marks" for actual quotations from authors.

2. I have explored pockets of the same territory, but frankly without the same depth of knowledge that Bernstein possesses of either the pragmatist tradition or the phenomenological tradition, in my 2008 and 2000. Having now read Bernstein's The Pragmatic Turn, however, I am pleased by the fact (or so it seems to me) that so much of what I think about the history of American philosophy seems to be in harmony with the views of someone who really knows what he is talking about, and who has been articulating many of the insights of the more recent 'New Pragmatists' for over half a century. In particular my brief comparisons between the early Peirce and Sellars on inferentialism and the myth of the given in my 2008 express views that were already anticipated by Bernstein in his 1964 article on "Peirce's Theory of Perception" and are now further developed in multiple locations in The Pragmatic Turn (e.g., p. 27, 46-9, 129-38), among other places.

Embarrassingly, however, I omitted to cite Bernstein either in those works or in my book on Sellars (2007), despite the fact that as a graduate student in the 1980s I had read and profited from Bernstein's thoroughgoing 1966 examination of Sellars' philosophy. The latter was the first full scale critical study of Sellars' entire systematic views up to that time, and having now re-read those articles of Bernstein - and having myself in recent years acquired a thorough knowledge of Sellars' philosophy - I am again impressed by the accuracy and critical insights of Bernstein's views in comparison with some more recent commentators on Sellars. I hope that with this opportunity I can make at least partial amends for my earlier omissions.

3. Hereafter page references without name or date are to Bernstein's The Pragmatic Turn (2010).

4. Crispin Wright on 'superassertibility' is another important development of this conception, as are aspects and stages in the thought of Putnam, Habermas, and other thinkers discussed by Bernstein in chapter 5 under the heading of "Ideal Justification and Truth."

\section{AUTHOR}

\section{JAMES R. O'SHEA}

University College Dublin

jim.oshea[at]ucd.ie 